DOI https://doi.org/10.18551/rjoas.2017-04.05

\title{
CAPITALISM PARADIGM SHIFT IN THE PRACTICE OF ORGANIZATIONAL HUMAN RESOURCE MANAGEMENT
}

\author{
Iskandar \\ Faculty of Economics and Business, Kutai Kartanegara University, Indonesia \\ E-mail: iskandar 76@rocketmail.com
}

\begin{abstract}
It is not easy to change the mindset about the importance of capitalism paradigm shift in organizational human resources management that is based on dignity and humanity. Capitalism is no longer just an economic system but the practice of human resources management in an organization. Therefore, the existence of human resources within the organization must be treated not as an 'asset' (means of production) but as people who have 'something'. By that, the role of leader and employee that complements each other is needed in order to change this capitalism issue. Until now, the networks and relationships which are formed by capitalism not only break the economic system but also change the behavior of human resources (HR) in the organization. The effect that came up because of this change is the spirit of individuality both in consumption and production. As a result, this condition makes the collectivity and solidarity become irrational. The competition skill as to gain the most, the highest, and to consume large quantities in order to receive a status symbol is a demand to enter and survive in the life of the capitalistic system. This paper is basically examined the effort of capitalism paradigm shift in organizational human resources management. In details, the writer wants to examine: (1) The paradigmatic struggle in human resources management and (2) change capitalism paradigm to deep ecology paradigm in the practice of human resources management in the organization. From here, the writer expects that this could change the attitude and behavior in the organization. In other words, the existence of human resources within the organization is essential to be treated not as an 'asset' (means of production) but as people who have 'something' not as an individual that "possessed" something.
\end{abstract}

\section{KEY WORDS}

Capitalism, human resources management, organization.

The failure of capitalism to build the welfare of mankind on earth turned out to bring the issue of economics death and is widespread among scholars. Many experts write a book that specifically talks about "The Death of Economics". For an instance, in 1994, Omerod wrote a book entitled "The Death of Economics". Omerod insisted that economists are stuck in a mechanistic capitalism ideology that it did not have the power to help and overcome the economic recession in the world. He believed that the market mechanism which is a form of the capitalist system tends to more concentrate on the wealth of certain groups.

Vadillo (1991) from Scotland who wrote the book of "The Ends of Economics" sharply criticized the injustice of the monetary system of capitalism. Capitalism actually had done a "robbery" to the wealth of developing countries through the monetary system of flat money that actually is usury.

Capra (1991a) revealed that conventional economics (capitalism) which is based on usury system has large flaws and errors in the number of its premises, especially in the economic rationalism that ignores morality.

This weakness led the economy capitalism to be unsuccessful in creating an economy justice and welfare for the people. Actually, the reality is in contrast to the assumption, the social gap has increased sharply in between countries and between the poor-rich community. This also happens similarly among the people in the country. Furtherly, they affirmed that in order to improve this situation, there is no other way except changing the paradigm and vision such as do a turning point in a civilization. What is meant by doing a turning point here is to build and develop a valuable and standard economic system that is accountable. 
The capitalist work networks and relationships not only have failed the economic system but also have changed the behavior of human resources in the organization. This causes a spirit of individuality both in consumption and production and a consideration that collectivity and solidarity are two irrational things. The ability to compete as to gain the most, the highest, and consuming large quantities in order to receive a status symbol is a demand to enter and survive in the life of the capitalistic system. A standard is no longer base on quality of "morality" anymore but on the quantity of human possessions. Moreover, honesty is no longer seen as a nobility of behavior.

By that, this has encouraged people to work as hard as possible for the sake of fulfilling their private desires. Capitalism is not merely an economic system but already an interfere in the practice of human resources management as well as in the values of life in which it also determines the direction of our lives.

Organization in a neighborhood of capitalism becomes powerless and unavoidably crushed in the swift capitalization. This means that the phenomenon above clarifies the current organizational practice that is steeped in the culture of capitalism in which it leads to a capitalist behavior.

Description of Changes. In this decade, a change seems to happen fast and continuous so that it pushes the managers to rearrange the strategy of the organization. The diversity of human resources that advance in communication and information technology has urged the organization to adopt a "new paradigm" or to see the world in a more sensitive, flexible, and adaptive way. This is stated to adjust the demands and expectations not only by the stockholders but also the stakeholders.

The old organizational paradigm that is based on a linear thought of mechanistic, topdown, rigid, and hierarchical structure has already shaken by the development of new science which encourages the growth of a new paradigm (Suhariadi, 2007). In other words, this system needs a new mindset both in the organizational understanding or human resources management.

Essentially, the changes that occur in the organization environment will change the strategy of human resources management in an organization (Drucker, 1999). The changes of organizational structure always refer to organizational strategy and the need of human resources that fill those requirements.

Based on these changes, it is necessary to improve the role of human resources manager in order to suit the era development. The condition above is illustrated by Suhariadi (2007) as a race between wooden and rubber boat where each team is trying to reach the goal or finish the fastest.

In general, we can say that we understand each position and mechanism of the boat. On each boat, the position of the men (subordinates) is located neatly on right and left the side, they are arranged very neatly so that the boat could move forward firmly.

Furthermore, we also understand the leader position which is placed in the front, face the men, and sit in a higher position so that all the men could see his direction and his command by using a drum.

The mechanism and rules of the wooden boat are:

Subordinates/employees who in this context are the men will row the boat by following the command of the leader; they would not start rowing without following the leader's command:

a) When the leader says "one two, three, four", the men will necessarily row the boat in accordance with the orders.

b) In this context, the men will not allow taking an initiative of working independently outside the leader's command.

c) When the leader told them to work, the men will do their work automatically, but, when the leader do not operate the work, the order will not effective for them. It is believed that the men never had a thought to row a boat without following the order of the leader.

d) If there are men who have the initiative to paddle the boat by themselves, then, they will ruin the pace so that it is very restricted to have them in the system.

e) The implication of this condition is that the men must follow a command when there is no leader and order, the men will not run their work. 
f) So, because of no leader, it is no wonder why there are many employees who do nothing while still in their work even though they might only read the newspaper, play chess, and play computer games. When they were asked about the actions above, the answer is that because of no command from their leader.

g) If the employees have such initiative in their work without having to wait for the leader's command, they fear that they might get scolded and fired if it turns wrong so that they always wait for the command in order to play safe.

The second rule in this system is that there is no protest from the subordinates. Every word from the leader is always correct, thus, it is considered that leader's command is like a king's decree:

a) When the leader gives a command "one, two, three, four", whether it is right or wrong, fast or slow, the command must be obeyed by the men.

b) If there is one man who disagrees with the command even doing a protest to the way leader gives his command which does not fit with the condition and in certain circumstances, the man wants to replace him, that man will necessarily get scolded and could be thrown from the boat.

c) The men who are not in line with the leadership style are considered as obstacles and opponents who can hamper the speed of the boat, they also regarded as a chatty, vocalist, and activist individual.

d) It is no surprise that the leader tried to remove the labeled men from the boat ("tidak segubang") so that the leader will do anything as long as the men could be exiled from the boat. This could be happened by eliminating them from the society, not giving them a job desk, or even fired.

e) According to the leader, the boat will accelerate with full speed as long as all men obey his order and that there is no protest within.

Then, the third rule that is needed to be understood is that the men cannot change their position especially when they want it:

a) When the boat is in motion in accordance with the leader's command, then, no one cannot propose to change their place due to a work fatigue.

b) When the men who are placed on the right side felt exhausted because of their right hands which do the work continuously, of course, there will be a desire to change the position so that they could alternate the left hands to do the work.

c) This condition makes the men to do a working replacement and to have a work shift so that there is a balance of work (a refreshing).

d) Of course, their wish will not be fulfilled due to the operation standard that there is no transfer, promotion, or demotion by the time the boat is on the way even though the men propose himself for the sake of balance.

e) The implication of this condition is that the organization (boat) will not perform employee's movements (transfer, promotion, demotion) when the boat drives.

f) Once a person is on a particular work and plays as a subordinate, then he/she will never move to other place or work.

g) As for this organization, the transfer of employee (transfer, promotion, demotion) would ruin the boat course.

h) The people can feel that the job is theirs once they first received it, anyone will not be allowed to replace it.

4. In general, the comprehension of this wooden boat can be understood in the context of the wooden boat race:

a) The wooden boat can go fast when the river is not in a swift wave and strong flow.

b) That is, the calm external condition makes the people predict various disruptions.

c) The character of a wooden boat that is hard and rigid means that a calm external condition shall be organized and arranged in a rigid or hard way.

d) The regulation or operation standard of a wooden boat follows the three rules above.

Furthermore, the mechanism and regulation of rubber boat can be seen as follows:

1. The position of the men (subordinates) does not need to be in one place due to a safety issue. The men must do a certain movement so that they will be safe; when the boat is started to sway, then, the men must follow the rotation direction. Every member of the 
organization is required to move and do a boat rotation if they want to be safe until the finish line.

2. The position of the leader in a rubber boat is almost the same with the subordinates.

a) Sometimes, the leader must be in the front line, in the middle, or on the back side which in Javanese is called "Ing ngarso sung tulodo, ing madyo mangun karso, tut wuri handayani".

b) This leader's moving position is a must so that boat can be safe.

c) However, the most interesting case in this movement is that when the boat strikes the rocks, the boat will be tilted so that the men will move to one place, in this position, the leader must move across the men

d) The opposite position, in this case, is not intended to go against the subordinates but to balance the boat.

e) This means that when an organization is experiencing a problem, instead of between the subordinates, the leader must be in opposite position so that it will balance the boat (organization).

3. This is similar to the previous explanation of wooden boat, this rubber boat does not care about the rank of leaders and subordinates; when everyone is in the boat, everything will work together to make sure that the boat will not get inverted.

a) In this case, without the command from the leader, all men would work together, the leader position, in this case, is just to keep an eye on the speed.

b) However, the leader role can also be replaced by men, all people can be active and shout to each other so that the boat will stay safe. Anyone can yell without having to consider the position, rank, and group.

c) The implication of this condition is that all people within the organization will work without command. Whether there is a leader or no leader, people will keep on working to run the organization.

4. In a wooden boat, the men who are vocal and not loyal will be removed by the leader; this is in contrast with the condition that happens in the rubber boat.

a) Whoever he is and wherever his origin is, if he fell into the river because of the boat that was hitting the rocks, he will be helped necessarily by the crew.

b) Thus, the implication of this system is that when there is one member who fell, all members will be attempted to help without seeing his rank, position, religion, race, and group.

c) The most important thing for the people in this rubber boat is that if we come together, then, we must leave together.

5. The presence of complete understanding of organizational procedure in rubber boat.

a) On an unpredictable condition (external environment), the boat which should be used in facing this kind of problem is a rubber boat with the rules that have been stated in point 1 up to point 4 above.

b) The question which should be kept in our mind is that are we going to face such quiet external condition or an unpredictable condition in the organization.

c) It is obvious by considering the condition of today's globalization or the future that environmental situation cannot be controlled externally and cannot be determined by the investors. Therefore, consumer's power is the one who could determine the situation; consumer's power that follows the market trends freely is difficult to be predicted.

d) The producer cannot arbitrarily make a linear prediction over the various event in the past, various kinds of turmoil, obstruction, and obstacles that are only temporary. Indeed, this kind of prediction can interfere the organization.

e) There is a complex construction which involves various kinds of the variable in calculating the benefits and disadvantages. However, note that these variables have different interest and should be considered by the policy maker (authorized party).

f) If it is clear that the condition ahead is unpredictable, the proper boat that should be used is the rubber boat. This means that the organization will be led in a flexible and non-rigid way. 
g) If we still insist on using the rigid and hard wooden boat, undoubtedly, we can predict that the boat will be destroyed right after it strikes the rocks.

h) Some government hospitals ( \pm 13 hospitals) have switched the status to be Public Service Board (Badan Layanan Umum or BLU). The management pattern in BLU is particularly provided for those units who conduct the operational task of public services such as health service, education, area management, and license) to distinguish government functions as policy regulator and determinant.

i) Actually, this practice has been developed largely in foreign countries as an activity identification that should not be done by pure bureaucratic institutions but by business like agencies so that the service that is delivered to the society becomes more efficient and effective.

j) This is a good example of organization flexibility (adaptation ability) towards globalization.

After what we have seen from the conditions above, it seems that there must be a fundamental change in assessing the human resources in an organization. At least, this perspective is based on the philosophy that human being is an individual who "owns" nature not as an individual that is "owned" by nature.

If we could see, nowadays, human resources empowerment and treatment in the organization are still placed as an "asset" that must be held for production activities. This condition confirmed that human resources management practice in the organization still in the perspective or paradigm of the mechanistic capitalist economy.

Human (employees) in an organization often be seen as a "tool production "or" assets "which equivalent to other assets such as money, material, machine, and method (in terms of management, it is known by the name of $5 \mathrm{M}=$ man, money, material, machine, method). This was caused by the absence of fundamental change on how we see the people in the organization. This means that the people are still considered as an individual who is "owned" by nature, not as an individual who "owns" nature.

On further developments, the label of human as an asset is calculated deeply so that every human development program will be associated by ROI (return on investment). Treating human as an asset should be calculated for its advantages and disadvantages which in this case human is really considered as a human capital. In other words, every rupiah that is issued by organization or institution must be synchronized with the investment and the ROI level must be calculated.

However, in its development, the science that sees human as an asset is developed even more rapidly than the science that manages human as the "owner" of nature. In this case, it can be understood easily to calculate human as an asset in the form of linear formulation and it is way easier to predict how many profits that will be acquired when a human is calculated as an asset. Thus, human dignity will be merely seen as a temporary asset or production means.

When the practice of human resources management is only seen in the framework of human as production means that must be owned by certain parties, automatically, there will be a mindset of human as something to possess and not as something to be.

In paying attention and reviewing those conditions, we must return to the principle of humanities whereas a human is not an object of possession but as a part of nature that grows in harmony and would not destroy the universe for their own interests.

Paradigmatic Struggle. The practice at of human resources management in the organization cannot be separated from the perspective or paradigm of the capitalist economy. This practice is reflected in such things, which are:

1. Industrialization era which is marked by the discovery of steam engine by James Watt. This invention led to the replacement of human labor with mechanical power. After that, there was a separation between human that working with tool production. This case encouraged the development of the mass industry with all kind of its management consequences. A machine or engine was a main tool in the production process to increase the company's welfare. Then, the importance of machine entered the aspects of human life so that our way of thinking and acting became mechanistic. The practice of human resources management in an organization that was developed in industrialization era refers to the 
paradigm that organization as a machine and human as one part of the engine (Morgan, 1998), this, of course, ultimately aims at an efficiency and affectivity (Suhariadi, 2007).

2. Today's information era actually has changed the organization drivers. An ownership of capital, natural resources, cheap labor, machinery, and technology do not ensure that the organization will be good in the population. This era is very selfish in a matter of ownership and knowledge mastery so that the main driver to survive in this age is to have a good knowledge of its members. The knowledge within the organization needs to be managed and improved which is known as a knowledge management. Tuomi (1999) and Nonaka (1995) divide the knowledge within an organization into two, namely: Implicit (tacit knowledge); and Explicit knowledge.

The task of the organization manager is to make the tacit knowledge into the shared explicit knowledge. In this era, the organization is certainly needed such knowledgeable workers. In order to survive, the organization should change the pattern of human resources management in the organization. The knowledge that is possessed by the organization member will also be gone if the member leaves the organization. This does not work like a machine that permanently stays although the operator left the organization.

Nevertheless, the point is that the era above (either industrialization era or information era) seems to be still engaged with the perspective or paradigm of capitalist mechanistic economy. The perspective above is different from the view of "deep ecology" that considered human being is proceeding and evolving with the universe to reach a higher level of life (Capra, 1991b). Human as part of the universe is not an asset but as God's creature that has various dimensions such as physical, biological, psychological, social, cultural, and spiritual.

Therefore, it is considered inadequate if the placement of an employee on certain position is only with measured through the psychological aspect. Recruitment and placement of an employee should be assessed appropriately through the assessment center.

The practice of human resources management within the organization by using deep ecology paradigm must be advanced in empowering the people. Apart from that, a true potential development is needed to be done so that it could work both for the organization as well as for personal development. In other words, human resources management should be able to produce "human work" (perikarya) and not "human labor" (bekerja). This paradigm should be the basis for lectures in both undergraduate and postgraduate degree in the field of economics or management. This thing needs to be established so that people, especially students can understand the man's position in the organization, thus, when they are in the society, they will be able to act as an agent of change for this new paradigm (Suhariadi, 2007).

Paradigm Shift. Positioning human as an individual who "has" something is not an easy task because the concept of "man as an asset" in the various organization is still very strong. According to the perspective or paradigm of the capitalist mechanistic economy, placing a man as an asset will be easier than treating them in correspondence with dignity and humanity.

In another word, we can say that paradigm shift from capitalism to deep ecology in the practice of human resources management is not easy. This is related to the need of dignity and humanity enhancement. If this condition is not a necessity, then, this will be difficult to change the intrinsic paradigm. At least, there are 4 key factors of paradigm shift in the practice of human resources management in an organization (Suhariadi, 2007) such as time, loyalty, trust, and productivity.

The first is about "the available time" which will be used by the employee to express the new values of humanity and dignity enhancement. The point is that the organization should provide sufficient time for an employee to always try or exercise the new values and also room, time, and place to fix the consequences of the new values adoption.

Secondly, is the "trust". Through trust, the community will build togetherness to change the old values become the new value that respects human dignity. Furthermore, this also could generate confidence (trust) among fellow members of the organization (managers and subordinates); not only build the aim together but also create a society that appreciates each other. Note that an organization not only provides sufficient time for employees to exercise but also gives a full trust for the employees. With thus, employees will feel valued and treated as adults so that they will be able to show an appreciation as the feedback. 
The third is about "loyalty". Loyalty is an emotional contract of employees that have the meaning in the form of availability to perpetuate the relationship with the organization. The essence of this factor is the total devotion of all abilities to the organizations without having to insist on the organization.

And then, the last is "productivity". Finally, all form of organization, group, or individual performance will be ended in productivity. The emphasis here is on the productive behavior of someone which is the behavior of employees which are oriented in the efficiency of resources utilization as well in the power and effectiveness of achieving an aim (Suhariadi and Yuwono, 2004).

A productive behavior in organization will be achieved when the aspects of leadership, trust, and loyalty can be held in the organization. Productive behavior will be a fundamental behavior when the individual finds the meaning in their work. When the work within the organization means a lot for the individual, then, the productive behavior will be maintained. To get the meaning on the job, a person must have a chance to develop his potential and value. This means that the management of human resources not only should be based on the potential capability or capacity but also the weaknesses.

So far, the mechanistic paradigm of capitalism emphasized the potential development of human resources development that is based on weaknesses and improved through training. By that, it is believed that the member of the organization is supposed to be aware of their advantages and strengths. Other than that, they also have a similar vision and value which are fostered and promoted from the bottom.

The basic potential development of human resources above will decrease the silence (voiceless) employee within the organization and fix the entire organization aspects.

Therefore, those four key changes should be based on the following three commitments, such as:

Intellectual commitment which is a logical commitment or determination (common sense) that the management of human resources in the organization should be able to give an additional economy value to increase the employee's welfare;

Emotional commitment which is an emotional commitment or determination (sincere heart) that the management of human resources in the organization is a shared task (social awareness) and there must be an addition of social value within;

Spiritual commitment which is a spiritual commitment or determination that is based on religious or spiritual values which propose that the human resources management in the organization is a matter of worship to get a blessing from Allah SWT.

\section{REFERENCES}

1. Capra, F. (1991a) The Turning Point: Science, Society and The Rising Culture. Bantam Books, New York.

2. Capra, F. (1991b). The Hidden Connection, A Science For Sustainable Living. Anchor Books, A. Division of Random House Inc., New York.

3. Drucker, P.F. (1999). Management Challenges for the $21^{\text {st }}$ Century. Herper Bussiness, New York.

4. Morgan, G. (1998). Images of Organization. Sage Publication. Thousand Oak, CA.

5. Nonaka, Ikujlro, Takeuchi, H. (1995). The Knowledge Creating Company. Oxford University Press.

6. Ormerod, P. (1994). The Death of Economics. Urizen Books, New York.

7. Suhariadi, F., Yuwono, I. (2004). Rumpun IImu Humaniora: Suatu Pemikiran dan Bahan Diskusi, Seminar Rumpun Ilmu di Universitas Airlangga, Surabaya.

8. Suhariadi, F. (2007). Paradigma Pengelolaan Manusia Di Dalam Organisasi: Bidang IImu Manajemen Sumber Daya Manusia, Pidato disampaikan pada pengukuhan Jabatan Guru Besar dalam Bidang IImu Manajemen Sumber Daya Manusia pada Fakultas Psikologi Universitas Airlangga, Surabaya.

9. Tuomi, I. (1999). Corporate Knowledge. Helsinki.

10. Vadillo, U. (1991). The Ends of Economics: An Islamic Critique of Economics. 1st published. Granada: Madinah PressSan Gregorio Alto, 30, 18010, Granada. 